\title{
献立のパターンに関する実態調查
}

\section{An Investigation on the Dietetic Pattern}

\author{
大都市と近郊小都市の献立調査 \\ A Dietary Survey in a large city and suburban town
}

\author{
国立栄養研究所 \\ (The National Institute of Nutrition) \\ 平 山昌 子 (M. Hirayama)
}

When we make a standard menu suitable for Japanese, it is necessary to know the actual dietetic pattern prevailing among them. This report is concerned with the results of a survey on pattern of menus of breakfast, lunch and supper of the general households in a large city and a suburban town.

This kinds of side dishes were full of variety, and the numbers of these dishes were per 100 households, 89 in breakfast, 121 in lunch and 125 in supper. Misosoup and Tsukemono(pickles) were most widely utilized followed by raw eggs, broiled fish and "Ohitashi(boild vegetables). It seems that these kinds of side-dishes are most typical patterns still prevailing among Japanese people.

About $36 \%$ of the households surveyed prepared 3 dishes a meal.

As the staple foods, rice was mostly utilized either in breakfast, lunch and supper. Bread was used more in the large city than in the suburban town which was the most striking difference between these two areas.

Of the protein sources eggs and fish were prominently employed in both the areas.

The proportion of the cooked foods and uncooked foods such as raw eggs, natto, ham, sausage and fresh vegetable was also observed. More uncooked foods were used in the large town throughout three meals, especially in breakfast about a half was served uncooked.

標準献立を作成する場合, 実際に行なわれている食事形態を把握して, 実態に即したものを作ることが大切 である。

そこで一般家庭において行なわれている朝, 昼, 晚の献立について, その栄 養的な評価はさておき，形態的な面の調査を行なった。

対象として選えだ地区は神奈川県下の大都市横浜市と近郊小都市伊勢原町で ある。

\begin{tabular}{|c|c|c|}
\hline 時 期 & 地 域 別 & 世帯数 \\
\hline $\begin{array}{c}\text { 1964年 } \\
11 \text { 月 }\end{array}$ & $\begin{array}{l}\text { 横 浜 市 } \\
\text { 伊勢原町 }\end{array}$ & $\begin{array}{l}44 \\
53\end{array}$ \\
\hline
\end{tabular}

世帯数は横浜市 44 世帯, 伊勢原町 53 世帯で, 調查を行なった時期は昭和 39 年秋である (第 1 表)。

\section{調査方法}

39年度国民栄養調查の資料をもととし，各家庭の書込久式で記録されたものを原票として献立名，飡，外 
食など記載のないもの，その他不備な点のあるものは集計より除外した。

\section{成績と考察}

〔副食の種類】各家庭でつかわ机ている副食の種類を全世帯合計してみると朝食では横浜市39種類, 伊勢原 町47種類，昼食沈れぞれ $56 ， 61$ ，夕食は61，64種類であった（第 2 表）。

第 2 表 副食の種類数

\begin{tabular}{|c|c|c|c|c|}
\hline & \multicolumn{2}{|c|}{ 横 浜 市 } & \multicolumn{2}{|c|}{ 伊 勢 原 町 } \\
\hline & 実 数 & $\begin{array}{l}100 \text { 世 } \\
\text { 带当 }\end{array}$ & 実 数 & $\begin{array}{l}100 \text { 世 } \\
\text { 帯当り }\end{array}$ \\
\hline あさ & 39 & 86 & 47 & 89 \\
\hline ひ る & 56 & 127 & 61 & 115 \\
\hline よる & 61 & 139 & 64 & 121 \\
\hline
\end{tabular}

これを 100 世帯単位になおして比較してみると朝食は横 浜市, 伊勢原町とも 89 種類, 昼食は 127 と 115 種類, 夕食 は 139 と 121 種類で大都市の横浜市の方が近郊小都市の伊 勢原町に比して副食の種類がやや多く, バライティーにと えでいるかのようであるが大きな差はない。

副食の内容についてみると（第 1 図-a-b-c）朝食で はみそ汁，つけものが全体の $29 \%$ と $25 \%$ を示し，依然とし て日本人の食生活パターンの中でこれらが優位を占めている。ついで生たまご，つくだ乽類が $10 \%$ と％，な っとう, めだま焼・たまご焼,のりなどがこれに次ぐ副食であった。

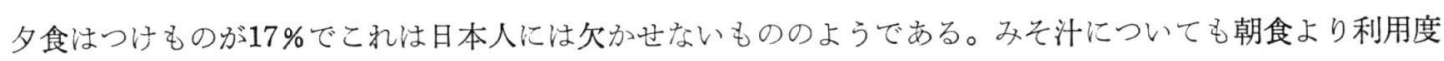
が少ないとはい光 8 \%を占め, 清汁 6 \%より頻度が高い。主菜として一番つかわれている副食は焼魚であった (第 1 図-b)。薏魚は 4 \%である。おひたしの頻度が $5 \sim 6 \%$ と比較的高いのは調查時期が秋であるという特殊 性であろうか。カレーは $2 \sim 3 \%$ ，その他の副食は, 図に示すように $9 \sim 8$ 回のもの 2 種類, $7 \sim 6$ 回の もの 5 種類， $5 \sim 3$ 回，2 1 回などの使用頻度のものがほとえどを占め, 各家庭の副食は多岐多様であると いうことが認められた。

第 1 図一a，副食の種類（あさ）

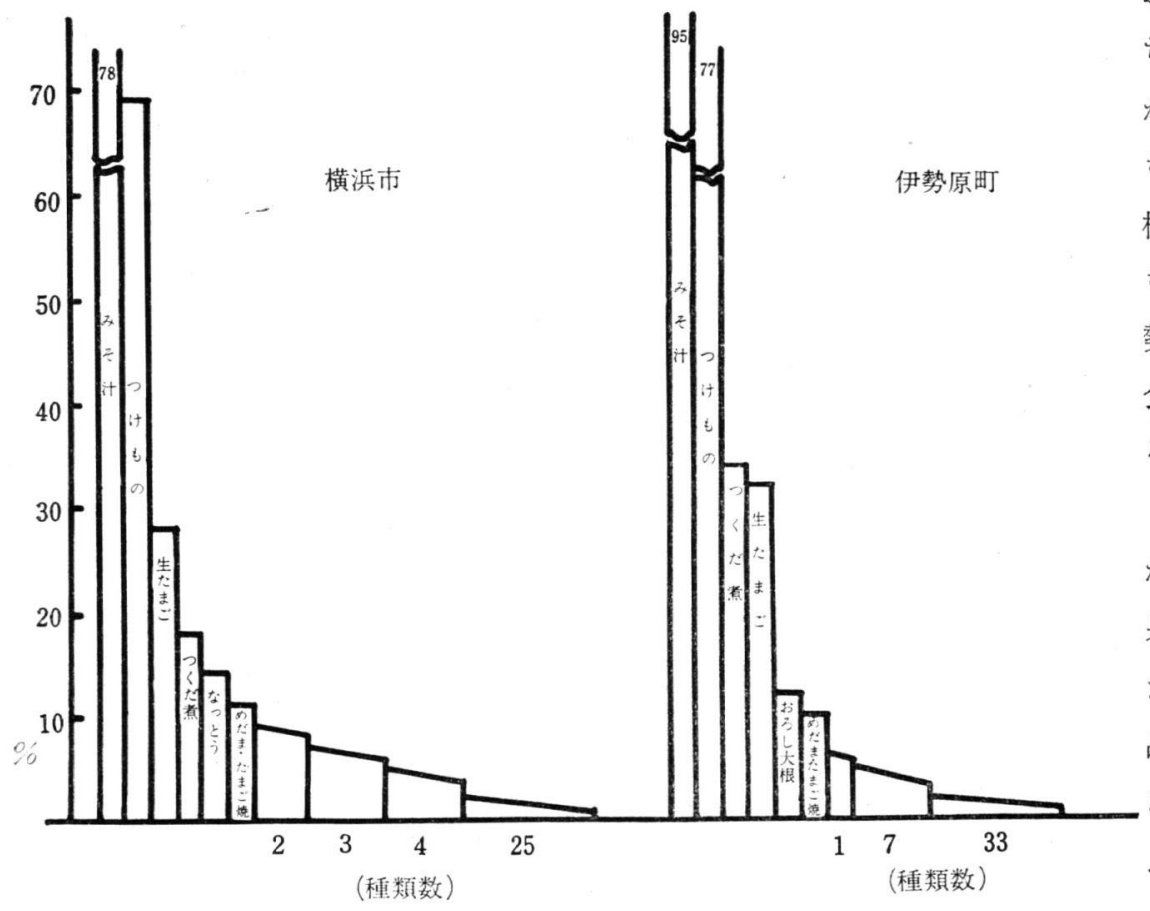

〔副食の品数〕 1 食に おける副食の品数すなわ ち，何品使用されている かをみると朝食, 夕食と も 3 品がもっとも多く, 横浜市では朝食, 夕食と も38\%がこれに属し，伊 勢原町では朝食 $44 \%$ ，夕 食 $35 \%$ が 3 品使用してい る。

朝食に沶いて 4 品の方 が 2 品より多いという結 果を得たが，これはつく だ惹，ふりかけなどを 1 品として集計した結果で あろうと考えられる。以 上を図示すると第 2 図の ようになる。 


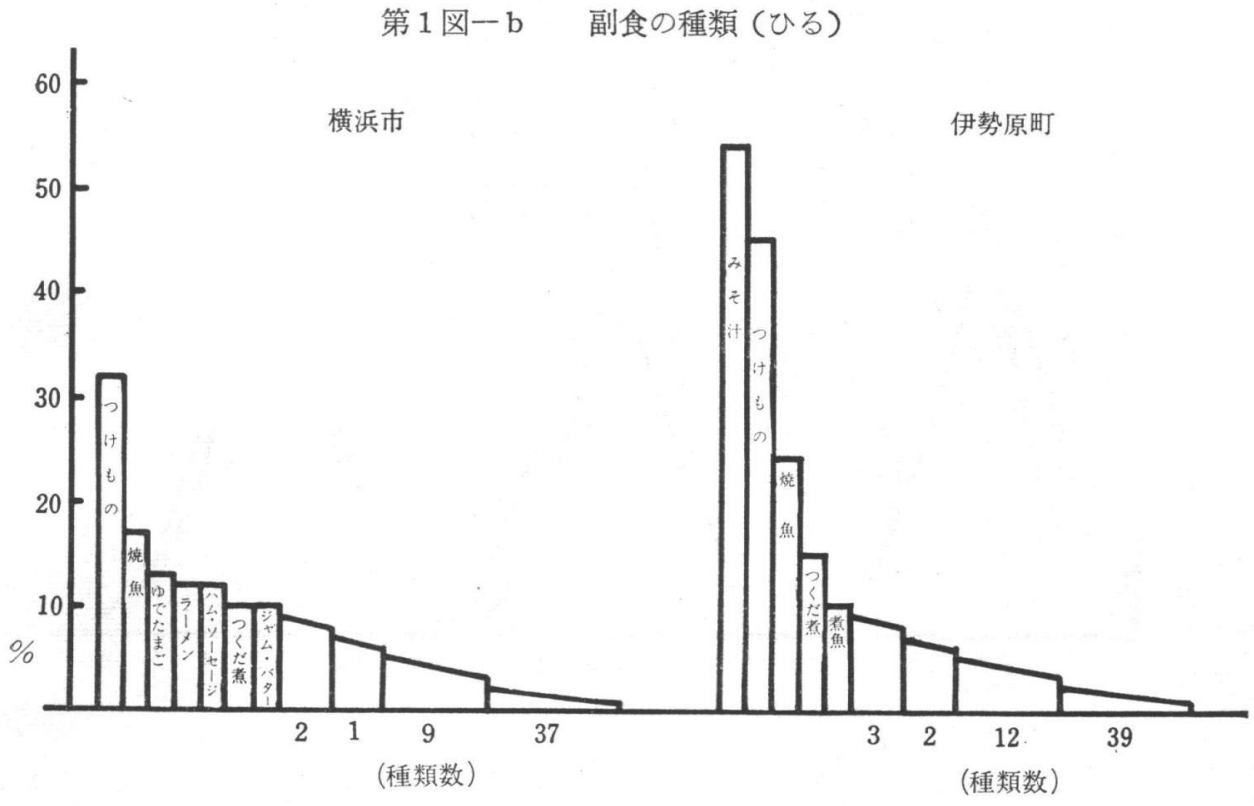

第 1 図一c 副食の種類 (よる)

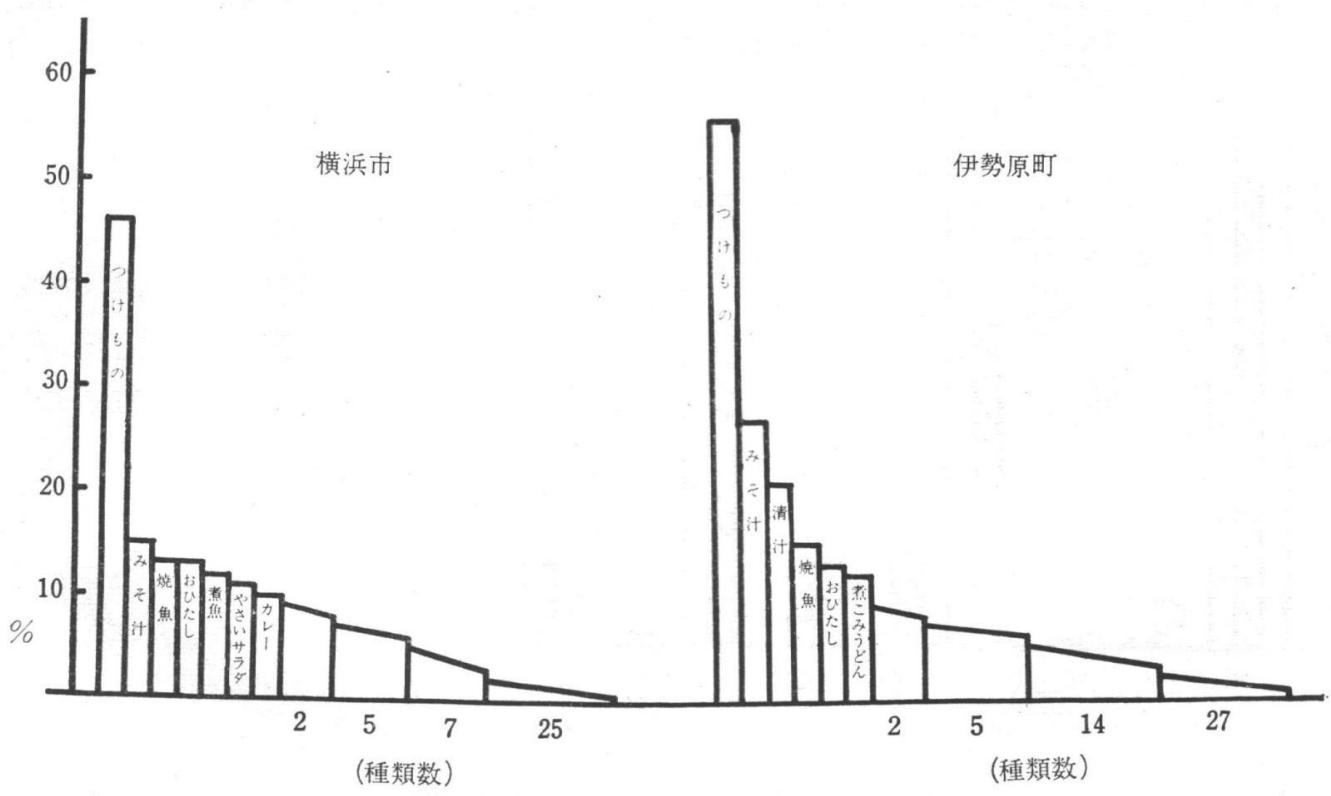

朝食の副食の種類数が昼食, 夕食のそれより多いということは, 朝食は量的あるいは質的に十分でない簡単 なものが供せられるために種類は品数が多くなり, 夕食は朝食とは逆に量, 質ともに充実した食事が供せられ ている故に品数としては朝食に比して少ないものと考えられる。このととから品数と食事の内容と注必ずしも 平行しないということができる。

昼食は 2 品か 3 品が多くこの間には差がなかった。横浜市, 伊勢原町とも昼食の副食は朝食か前日の残りの ものを使用するという例が多かった。横浜市は 2 品が一番多く, 伊勢原町は 3 品が上位を占めている。このこ とは副食の種類ともあわせ考えて横浜市は給料生活者が多く, 主人が外で食事をするために家族の食事は簡単 
第 2 図副食 $の$ 品数

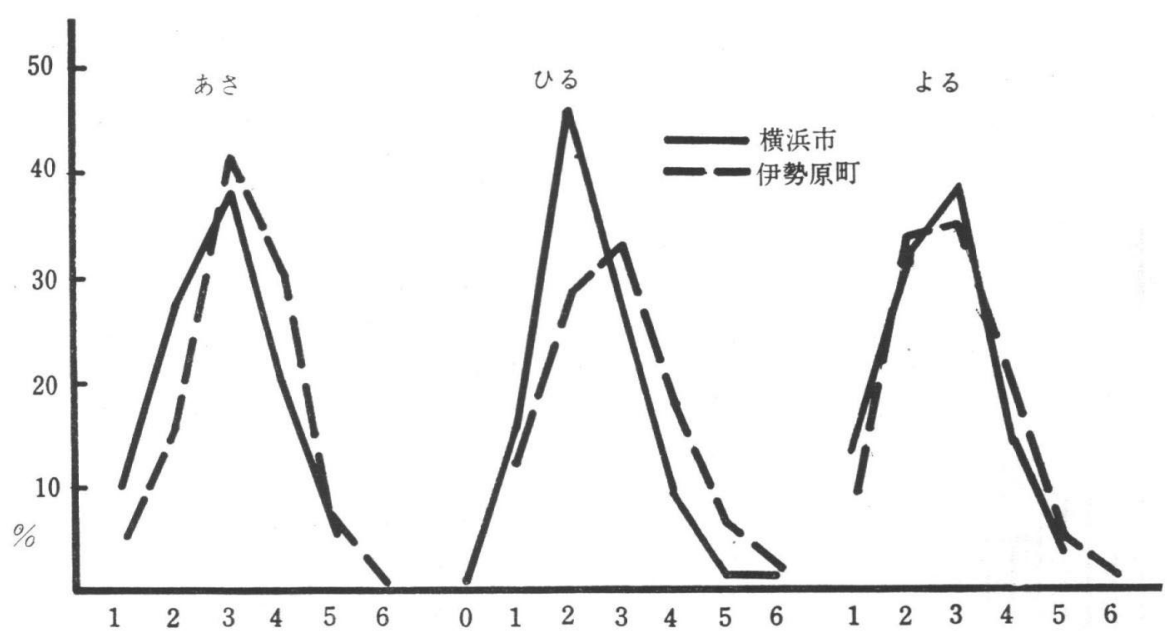

品

になりがちであるが，伊勢原町は自家営業の家庭が多く主人と共に昼食をとる例が多いのではないかと推察さ れた。

〔主食について〕主食の種類を餄, パン, 麵類に分けてその利用度を己ると(第 3 図), 朝食では横浜市は飯 第3図主 食の 形 態

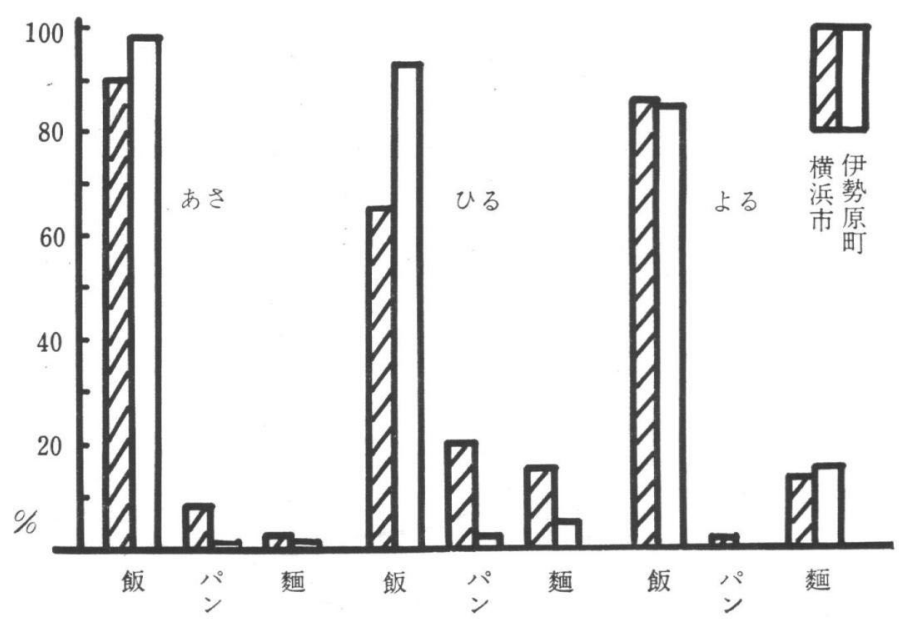
$90 \%$ ，パン $8 \%$, 麵類 $2 \%$, 伊勢原 町は飯 $98 \%$, パン, 麵類はそれぞれ $1 \%$ で朝食の主食は両地区ともだん ぜえ飯が多い。

昼食では横浜市では飯 $64 \%$, パン $20 \%$, 麵類 $16 \%$ と，パン，麵類がら えているが，伊勢原町では93\%，2 \%, 5 \%で，そのふえ方は少ない。 夕食では飯 $86 \%$ と $85 \%$, パン $1 \%$ ， $0 \%$, 麵類 $13 \%, 15 \%$ で両都市間に 差はみられなかった。以上のべたよ

うに朝食および昼食におけるパンの 利用度は横浜市と伊勢原町とではか なりの差が認められた。そしてこのことは主食利用率における大都市と近郊小都市の特徴のあらわれであろう と思われる。

〔たんぱく源の分布】次に観察の角度をかえて，たえぱく源の分布の状態をみた。

たえぱく源として用いられている鷄卵, 獣鳥肉, 魚肉, 大豆の使用回数をしらべてみると, 第 3 表にみるよ うに朝食では両地区平均にたえぱくの摂取の $69 \%$ \%たたまこによって占められている。獣肉，魚肉の使用につい ては横浜市, 伊勢原町の間に差がないが，大豆は都市である横浜市が近郊小都市の伊勢原町の 2 倍も利用して いることは興味あることである。

昼食は残りものの捸取が多いということからバラつきが多い感じであるが，両地区とも魚が多く，5\%以上 
第 3 表 たえぱく源の使用頻度

\begin{tabular}{|c|c|c|c|c|c|c|c|}
\hline & & あ & さ & ひ & る & よ & る \\
\hline & たまご & $89^{\text {⿷匚丿 }}$ & $62^{\%}$ & $36^{\text {茊 }}$ & $32 \%$ & $12^{5}$ & $8 \%$ \\
\hline 横 & 獣 肉 & 5 & 4 & 31 & 28 & 55 & 37 \\
\hline 浜 & 魚肉 & 22 & 15 & 43 & 38 & 79 & 53 \\
\hline 市 & 大 豆 & 27 & 19 & 2 & 2 & 4 & 2 \\
\hline & たまご & 115 & 76 & 30 & 17 & 23 & 13 \\
\hline 伊 & 獣 肉 & 8 & 5 & 34 & 19 & 61 & 34 \\
\hline 原 & 魚 肉 & 17 & 11 & 100 & 55 & 91 & 50 \\
\hline 町 & 大 豆 & 12 & 8 & 17 & 9 & 6 & 3 \\
\hline
\end{tabular}

のを使用しており，伊勢原町でも36\%は非調 理食品であった。このことは朝食には手をか けずに食するものが多く利用されているとい うことと, 大都市の横浜市の方が給与生活者 が多いのではないかと推察された。

昼食については横浜市 $25 \%$, 伊勢原町 $14 \%$ 夕食は横浜市 $11 \%$ ，伊勢原町 $8 \%$ がそれぞれ 非調理食品で, 昼, 夕とも横浜市の方が非調

\begin{tabular}{|c|c|c|c|c|c|c|}
\hline & & $\begin{array}{l}\text { 調 理 } \\
\text { 食品数 }\end{array}$ & $\begin{array}{l}\text { 非調理 } \\
\text { 食品数 }\end{array}$ & 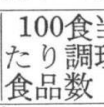 & $\left|\begin{array}{c}100 \text { 食当 } \\
\text { た り詮調 } \\
\text { 理食品数 }\end{array}\right|$ & \begin{tabular}{|c|} 
非調理食品 \\
調理食品
\end{tabular} \\
\hline 横 & あさ & 407 & 179 & 188 & 83 & 44 \\
\hline 浜 & ひる & 308 & 78 & 160 & 40 & 25 \\
\hline 市 & よる & 454 & 48 & 217 & 23 & 11 \\
\hline 伊 & あさ & 620 & 223 & 238 & 86 & 36 \\
\hline 勢 & ひる & 634 & 92 & 246 & 36 & 14 \\
\hline 町 & よる & 669 & 54 & 256 & 21 & 8 \\
\hline
\end{tabular}
区ともたんぽく攝取の $70 \%$ はたまごと魚肉から得てい ない。

〔調理, 非調理の副食数について】生たまご,なっ とう, 低煮, ふりかけ, 八ム・ソーセージ, 梅干, 生 やさいなどのように加熱せずそのまま食しているもの と, 加熱調理をしたものとの比をみると第 4 表のよう に横浜市では朝食の約半分近くは加熱しないままのも。 理食品の利用が高かった。

が魚を利用している。これを 3 食平均してみると両地 ることになる。獣肉の使用度は回数としては比較的少

\section{総括}

日本人の食事形態の近代化が進みつつあるといわれている今日，実際にはどのような形の献立が一般に行な われているかをみるために大都市横浜市と, その周辺の小都市伊勢原町とにおいて献立の実態調查を行なった ところ, 両地区を通じてその献立の大部分は依然として日本人古来の㫮好をあらわすようなものであった。

すなわち, 朝食にはみそ汁, 生たまご, つけものというようなパターンが圧倒的に多数を占め, 昼食は朝食 や前日の残副食で簡単にすませているのが多い。夕食にはある程度の重点がおかれてはいるが, 従来の形式に よる日本料理的パターンが多い。一部には外来の食品を使用したいかゆる欧米風の献立も用いられているが決 して多くはない。

豆動物性たえぱく源として最も多く使用されているのは朝, 昼, 夕を通じてたまご, 魚肉で, その他獣肉, 大 もたんぱく源として比較的多く使わ秃ている。

以上の観察から大都市である横浜市と小都市伊勢原町との間には，おのずからその特徴があらわれており， 伊勢原町の自家営業者の多い地域との差がみられた。

この種の調查は今後さらに資料を集積して, 日本人の食事形態の実態を把握し，その欠陥を見いだして今後 の栄養指導の参考としたいと思う。

（受付: 昭和 42 年 1 月 15 日） 